\title{
Når lærlingen møter arbeidslivets vurderingslogikk: Yrkessosialisering i det norske salgsfaget
}

\author{
(The apprentice's encounter with the assessment logic of working \\ life: Vocational socialisation in the Norwegian sales trade) \\ Kaja Reegård
}

\author{
Fafo, Institutt for arbeidslivs- og velferdsforskning, Norge \\ (kaja.reegaard@nifu.no)
}

\begin{abstract}
The article examines the role of formative assessment to occupational socialisation processes in retail apprenticeship in Norway. The analysis draws upon a qualitative study of managers and apprentices in the Sales Vocational Education and Training (VET). The Norwegian sales trade struggles to gain foothold. The skilled sales assistant constitutes neither an established social category, nor an employee category. Sales VET is directed towards a labour market sector depicted in terms of high turnover, traditionally valuing soft skills and personality over formal credentials. The article aims to extend understandings of apprentices' subjective accounts of the assessment they are subjected to and coconstructing. Three different assessment practices integrated in the daily work are analysed. First, retail work centres on customer interaction. The feedback the apprentices receive from the customers, as a type of user-evaluation, provides rich and immediate learning resources. Second, the retail apprentices were thrown into tasks from day one, and are thus shown trust and given responsibility. This recognition by gradual access to more complex tasks serves as another type of assessment, implying increased self-confidence and sentiments of commitment. Third, the sales figures of each apprentice were transparently registered and monitored in the computer system of the shop, representing assessment as management control. By deploying the notion of assessment logic, the article argues that one is better equipped to grasp the interplay between learning, assessment, becoming and working in the retail sector. The interactive nature of customeroriented service work implies re-interpretation of the traditional assessment nexus of trainer - apprentice. The findings of the article show that the apprentices ascribed customer evaluation of great importance to their learning and becoming.
\end{abstract}

Keywords: assessment, vocational education and training, sales trade, interaction with customers, vocational socialisation

doi: 10.3384/njvet.2242-458X.2010367 


\section{Innledning}

Denne artikkelen tematiserer fagopplæringens plass i spenningen mellom læring og produksjon, og vurderingens rolle i "tilblivelsesprosessen" av en fagarbeider. Fagopplæringen som institusjon forstås dermed som noe mer enn en arena for tilegnelse av yrkesrettede kunnskaper og ferdigheter. I tillegg kan det ses om en identitetsendrende prosess der novisen sosialiseres inn i og av et faglig fellesskap, og internaliserer yrkesrelaterte holdninger, verdier og væremåter (Dall' Alba, 2009; Klotz, Billett \& Winther, 2014). Ulike former for formativ vurdering anses som vesentlig for denne prosessen (Ecclestone, 2007). Slike sosialiseringsprosesser griper inn i samspillet mellom faktorer på strukturelt, organisatorisk og individuelt plan. Fokuset i denne artikkelen er lærlingenes vei til å bli faglærte salgsmedarbeidere, og hvilken rolle vurderingspraksiser forankret i det daglige arbeidet, spiller i denne prosessen.

Analysene er basert på kvalitative intervjuer med salgslærlinger i et bredt spekter av butikker i Norge. De har først gått to år på skole, og er intervjuet midt i sitt toårige lærlingeløp. Fagbrevet de er på vei mot, står imidlertid lavt i kurs på arbeidsmarkedet. Arbeidsgivere rekrutterer i hovedsak gjennom andre kanaler enn fagopplæringen, og utdanningsprogrammet er preget av høyt frafall (Hagen, Nadim \& Nyen, 2010; Høst, Seland \& Skålholt, 2013). Men selv om disse lærebedriftene har liten erfaring med å tilby opplæring i fagopplæringsforstand, finnes lang erfaring med å lære opp unge. Sektoren er karakterisert av å være et ungdomsarbeidsmarked med utpreget deltidsarbeid og høy turn-over. Flere av de større kjedene har veletablerte systemer for internopplæring (Bore, Reegård, Nyen \& Tønder, 2012).

Butikken som læringsarena stiller andre spørsmål knyttet til vurdering sammenlignet med skolebasert læring, og i fag innenfor mindre kundeeksponerte sektorer. Det mest sentrale og unike for salgsarbeid er altså kundens rolle. For å analysere lærlingenes subjektive opplevelser av vurderingsformene de møter i det daglige arbeidet, argumenterer artikkelen for nødvendigheten av å forstå karakteren av, og logikken i salgsarbeid. Dette innebærer å se vurderingspraksisene som forankret i en spesifikk vurderingslogikk. Friche (2010) vektlegger hvordan vurdering inngår i et komplekst samspill av aktiviteter mellom elev-lærer (lærling-instruktør). Ved å forstå vurdering som en prosess forankret i det daglige arbeidet, tildeles de unge en aktiv rolle i studiet av vurderingspraksiser. Lærlingene forstås dermed ikke som "passive" mottakere, ofre eller objekter for de ulike vurderingspraksisene, enten det er formelle eksamener, tester, evalueringsskjemaer eller uformelle tilbakemeldinger. Derimot anlegges et perspektiv der lærlingene anses som medkonstruktører i sin egen sosialiserings- og identitetsarbeidende prosess. Der praksisbegrepet kan vekke assosiasjoner til tilstivnede gjøremåter, rutiner, skjematisk handling og sedvane, vektlegger logikkbegrepet et mer aktivt aktørperspektiv, der karakteren av logikken avgjøres etter ulike 
konfigurasjoner av hvordan sosiale strukturer begrenser, men også muliggjør aktørers handling (Thornton, Ocasio \& Lounsbury, 2012). Logikkbegrepet betoner dermed verdibaserte antakelser om kausale sammenhenger mellom virkemidler og mål innenfor et gitt system.

Denne artikkelen tar for seg tre aspekter ved detaljvarehandelens distinkte vurderingslogikk sett fra lærlingenes perspektiv. For det første analyseres kundens rolle i vurdering av lærlingenes jobb. Deretter analyseres vurdering gjennom tildeling av stadig økende ansvar som uttrykk for tillit. Til slutt, og i et motforhold til ansvarstildelingen, tar artikkelen for seg salgsregistrering som vurderingsform og et uttrykk for ledelsens behov for kontroll (Kvale, 2007). Dette er et system der de ansattes salgssummer registreres $\mathrm{i}$ et transparent datasystem $\mathrm{i}$ butikken. Disse to elementene, kunden og økt ansvar faller ikke så lett inn i konseptet "vurderingspraksiser". De representerer heller innebygde, definerende trekk ved salgsarbeidets organisering og natur. I neste avsnitt presenteres bakgrunnsinformasjon om det norske salgsfaget, etterfulgt av den analytiske innrammingen for studien. Deretter redegjør artikkelen for data og metode før lærlingenes møte med detaljvarehandelens vurderingslogikk analyseres og diskuteres.

\section{Bakteppe og metodisk tilnærming}

Analysene presentert i denne artikkelen var en del av en større studie som omhandlet ulike aspekter ved kvalitet i det norske fagopplæringssystemet, der rørlegger- og industrifag i tillegg til servicefag ble studert. ${ }^{1}$ Men det er salgsfaget som her står i fokus. Salgsfaget ble opprettet og integrert i det norske fagopplæringssystemet på videregående nivå på 1990-tallet. Siden da har salgsfaget strevd med å få fotfeste, både blant elevmassen og i arbeidslivet (Reegård, 2017). Da studien fant sted, inngikk salgsfaget i Vg1 utdanningsprogrammet service og samferdsel. Av de daværende 12 utdanningsprogrammene, var dette det sjette største basert på søkertall (3245 søkere til skoleåret 2015/2016) (Utdanningsdirektoratet, 2020a). Fra 2011 til 2014, var det vært en økning i søkere til service og samferdsel. Det var 512 søkere til Vg3 salgsfaget i 2014 (Nyen, Skålholt \& Tønder, 2015). Videre var det kun omtrent halvparten av de som søkte læreplass som ble lærlinger, og under en tredel som oppnår fagbrev på normert tid (Vibe, Hovdhaugen \& Markussen, 2012). Med den nye yrkesfaglige tilbudsstrukturen har dette utdanningsprogrammet blitt omdøpt til salg, service og reiseliv, der salgsfaget har fått en mer prominent plass enn tidligere (Utdanningsdirektoratet, 2020b).

Salgsfaget er rettet mot detaljhandelen som er den største tjenesteytende næringen (SSB, 2018). Til tross for at detaljhandelen utgjør et stort arbeidsmarked, er fagbrevets posisjon svak. Det betyr at det er en lav andel av ansatte i detaljvarehandelen som har fagbrev, og arbeidsgiverne kan ha lite kjennskap til fagbrevet. Faget er svakt etablert i den forstand at det ikke finnes noen klare 
forhåndsdefinerte yrkesstillinger reservert for den faglærte salgsmedarbeideren og tre inn i, der arbeidsgivere i stor grad rekrutterer ufaglært arbeidskraft (Høst mfl., 2013; Olsen \& Reegård, 2013; Reegård, 2017).

Det norske systemet, bestående av en såkalt 2+2-modell innebærer at det fireårige opplæringsløpet er organisert med to år på skolen (ispedd perioder i bedrift), etterfulgt av to år som lærling i en bedrift. Innholdet i det første året på videregående retter seg mot ulike deler av servicesektoren i bred forstand. I det andre skolebaserte året, skal elevene kunne spesialisere seg til salgsfaget. Den skolebaserte opplæringen består av kombinasjoner av felles programfag, som for eksempel kommunikasjon, økonomi og markedsføring, fellesfag, som matematikk, norsk og kroppsøving, samt faget yrkesfaglig fordypning, der elevene får erfaring med sitt valgte yrke i en begrenset periode $\mathrm{i}$ bedrift.

Denne artikkelen baseres på kvalitative intervjuer med salgslærlinger som var midt i sin toårige læreperiode i Norge. Samlet sett ble 11 lærlinger intervjuet, fordelt på ni forskjellige butikker. I tillegg ble lærlingenes nærmeste leder intervjuet. Selv om butikkene var svært ulike med hensyn til produktene de solgte, delte de mange likhetstrekk. For det første var alle del av en regional eller landsdekkende kjede. For det andre, arbeidet det mellom fem til ti ansatte i butikken, og for det tredje, var butikkene preget av flat organisasjonsstruktur, der lederen gjorde mange av de samme oppgavene som de ansatte. Tabell 1. viser oversikt over butikkene som inngikk i denne delen av studien.

Tabell 1. Oversikt over butikker og lærlingeintervjuer. ${ }^{2}$

\begin{tabular}{|l|c|}
\hline Butikk & Lærling \\
\hline Bilforhandler & 1 \\
Elektronikkforhandler A & 1 \\
Elektronikkforhandler B & 2 \\
Jernvareforretning & 1 \\
Dagligvarebutikk & 1 \\
Skjønnhet- og velværeforretning & 1 \\
Kiosk og videoutleie & 1 \\
Kjøkkenartikler og dekorforretning & 1 \\
Sportsbutikk & 2 \\
\hline Totalt & $\mathbf{1 1}$ \\
\hline
\end{tabular}

I tillegg til intervjuene, bidro begrenset etnografisk observasjon til å gi en følelse av stemningen i butikken, arbeidstempoet, press, samt innblikk i omgangstone de ansatte seg imellom og mellom ansatte og kunder. 
Undervisningen i den skolebaserte opplæringen bærer i stor grad preg av tavleundervisning og oppgaver knyttet til læreboka. I den bedriftsbaserte læretiden tar lærlingene del i det daglige arbeidet. Det viste seg at den bedriftsbaserte opplæringen i liten grad var organisert etter en intern opplæringsplan utarbeidet av daglig leder. Selv om opplæringen hadde en planløs karakter, var den ikke nødvendigvis uten mål og retning. Lærlingene fikk tidlig i læreperioden prøvd seg med bedriftens daglige oppgaver, i hovedsak salg og kundebehandling. Etter hvert som læretiden skred fram, fikk lærlingen andre oppgaver knyttet til et bredere spekter av salgs- og butikkarbeid. Dette kunne innebære utarbeiding av kampanjer og lage salgsutstillinger. Lærlingenes arbeidsoppgaver var relativt like på tvers av bedriftene. Samlet sett var lærlingenes arbeidsoppgaver varierte; bestille, ta imot, pakke ut, registrere og sette ut nye varer, varetelling, prising av varer, kasseoppgjør, vasking, rydding, samt lese om nye produkter på nettet (Olsen, Reegård, Seland \& Skålholt, 2014).

I neste avsnitt presenteres artikkelens analytiske rammeverk, før lærlingenes perspektiv på vurdering analyseres relatert til tre ulike vurderingsformer; tilbakemelding fra kundene, gradvis økende ansvar og salgsregistrering.

\section{Et vurderingsteoretisk rammeverk}

Nore og Lahn (2014) illustrerer hvordan den norske bedriftsbaserte opplæringen kan karakteriseres som et hybrid læringsmiljø. Med dette menes at læringsprosessene skjer i samspill mellom ulike institusjonelle aktører som opplæringskontor, bedrift og lærling iblandet kurs og e-læring. I det daglige arbeidet opplever lærlingene en rik tilbakemeldingspraksis. Sammenlignet med skolebaserte vurderinger, inngår lærlingene i et nett av ulike lærings-, arbeids- og vurderingsformer forankret $\mathrm{i}$ bedriften. Bedriftene vektlegger autentisitet $\mathrm{i}$ vurderingen. Det handler om at handlingene som skal vurderes skal springe ut av det daglige arbeidet og reelle arbeidsoppgaver (Gulikers, Bastiaens \& Kirschner, 2008).

I det følgende rettes fokus mot de uformelle vurderingsformene underveis, forankret i det daglige arbeidet som lærlingen og læringen er innvevd i. Først, formativ vurdering er rettet mot å utvikle og forbedre handling. Denne vurderingsformen kontrasteres gjerne til såkalt summativ vurdering som vurderer sluttproduktet av en aktivitet, ofte i form av en eksamen eller test (Tanggaard, 2004). Formativ vurdering forankret i det daglige arbeidet kan ha mange ulike uttrykk, som for eksempel et anerkjennende nikk, en klapp på skulderen, ros eller korrektiver fra kollegaer og leder. Slike vurderingsformer anses som konstituerende for læring, mestring, motivasjon og anerkjennelse. Disse formative underveisvurderingene forstås her som innvevd i det daglige arbeidet og læringen som derigjennom skjer. Videre, ved å anlegge et perspektiv som vektlegger "vurdering som læring", kan vanskelig vurderingsformene adskilles fra arbeids- og læringsaktiviteten - derimot er de dypt integrert. Det finnes en stor litteratur om 
hvordan læring og "tilbliving" (becoming) konstituerer hverandre (se f. eks. Colley, James, Tedder \& Diment, 2003; Hager \& Hodkinson, 2009). Yrkessosialisering i tråd med Berger og Luckmann (1990) ses som en form for styring som fører individene inn i samfunnet, her yrket. Lærlingene møter et sett av normer og verdier i yrkesfeltet, som de skal gjøre seg kjent med og internalisere, altså skape mening og gjøre til sine egne.

I et situert læringsperspektiv betones betydningen av sosiale situasjoner og sosialt situerte handlinger, der læring og kunnskap ikke bare er "noe man har, men der er også noe som former en, og som gir nye muligheter for handling og refleksjon" (Frønes, 1998, s. 32). Lave og Wenger (1991) beskriver denne prosessen der læring ikke ses som tilegnelse av kunnskap, men deltakelse i sosiale- og praksisfellesskap. Lærings- og den identitetsendrende prosessen analyseres gjennom lærlingens "legitime perifere deltakelse" til gradvis full deltakelse i praksisfellesskapet. Med andre ord, læring, vurdering og identitetsendrende sosialiseringsprosesser forstås som tre sider av samme sak, og konstituerer hverandre gjensidig.

Et slikt helhetsperspektiv på læring, vurdering og sosialisering, aktualiserer relevansen av å se lærlingens aktiviteter gjennom en særegen salgsvurderingslogikk. Salgslærlingene innveves i etablerte logikker i servicearbeid, produksjon, verdiskaping og organiseringen av dette arbeidet. Ulike kausale mekanismer som forbinder middel og mål, er i kjernen av logikkbegrepet. Salgsarbeid, sentrert rundt kunden, vurderes dermed å være kjennetegnet av en distinkt vurderingslogikk som adskiller seg fra, og går utover vurderingskultur. Vurderingskultur omtales ofte som normer, verdier og holdninger knyttet til hvordan bedriften oppfatter og praktiserer vurdering. Vurderingslogikk betoner imidlertid det gjensidig avhengige forholdet mellom lærlingen og arbeids- og læringsaktivitetene vedkommende former og formes av. Herigjennom anlegges et perspektiv der lærlingene anses som medkonstruktører i sin egen sosialiserings- og identitetsskapende prosess.

Fokuset i artikkelen rettes mot de formative underveisvurderingene forankret i det daglige arbeidet. I det følgende analyseres lærlingenes subjektive erfaringer langs tre akser: kundens rolle, økt tildeling av ansvar og salgsregistering. Dette på bekostning av et fokus på de mer formelle vurderingsformene knyttet til oppnåelse av læreplanmål på veien mot fagprøven. I analysene fremheves organisatoriske og kontekstuelle faktorer, og deres relevans for å forstå salgsvurderingslogikken og yrkesfaglig identitetsutvikling.

\section{Har kunden alltid rett?}

Salgsarbeidets virke dreier rundt kunden og det å bringe inn penger i kassa. Kundebehandling som definerende for arbeidets karakter impliserer ulike aspekter for arbeid og læring. Hvordan skal kvaliteten på kundebehandlingen og 
service vurderes, og hvem er best egnet til å gjøre dette? I store deler av den pedagogiske og fagdidaktiske litteraturen vektlegges betydningen av vurderingskompetanse hos vurderer, enten dette være seg lærer eller instruktør/faglig leder $i$ bedriften, samt sammenheng mellom vurderers vurderingskompetanse og elevens motivasjon (se f. eks. Engh mfl., 2012; Hidi \& Renninger, 2006). I læretiden i salgsfaget er det først og fremst kunden, som tredjepart, som gjør hoveddelen av vurderingsarbeidet. Kunden er ikke nødvendigvis en kyndig vurderer, men gir lærlingene like fullt umiddelbar tilbakemelding på servicen de har fått. Intervjuene viste at lærlingene tillegger tilbakemeldinger fra kunden stor vekt og verdi, illustrert ved sitatet fra Andreas som er lærling hos en elektronikkforhandler. Han ble spurt om hva han synes er det mest morsomme på jobb:

$\AA ̊$ gjøre en kunde fornøyd. Det å gi god service og selge mye til én kunde. Jeg liker å rette opp en misfornøyd kundes inntrykk. Det er vanskelig, men veldig morsomt. (Andreas, elektronikkforhandler B)

Da lærlingene ble spurt om hvordan de visste at de hadde gjort en god jobb, oppga de kundens umiddelbare reaksjon: "Hvis kunden er fornøyd, da vet jeg at jeg har gjort en god jobb" (Tina, kiosk og videoutleie). Mestring og anerkjennelse ble knyttet til kundeinteraksjon. Lærlingene opplevde det som motiverende og gøy når de klarte å gjøre kunden fornøyd - samtidig som de skaffet penger i kassa. En lærling i elektronikkforretning A forteller engasjert om da han klarte å snu en misfornøyd kunde om til en fornøyd kunde, og fikk et fast håndtrykk som takk. Kunden var også helt sentral i lærlingenes fortolkning av yrkesrollen, hva det vil innebære å være en salgsmedarbeider og hva som er de viktigste egenskapene en da bør ha. De anså det å se og forutse kundens behov, yte god service og få kunden til å komme tilbake, som helt sentrale deler av arbeidet. En av lærlingene fortalte at hver nye kunde representerte en ny sjanse for å gjøre en god jobb. Kvale (2007) viser hvordan kunden kan fungere som vurderer gjennom såkalt brukerevaluering. Kunden får dermed en rolle som bedømmer av lærlingens arbeid, for eksempel ved at kunden forlater butikken uten å kjøpe noe. Kvale omtaler dette som "evaluering med føttene".

På den ene siden ga kundebehandling rom for kreativitet, der lærlingene kunne prøve ut nye salgsstrategier. Kundeinteraksjon bød på en uforutsigbar lærings- og vurderingssituasjon. Dersom noe ikke fungerte, kunne de korrigere dette og justere kursen til neste kunde. Fornøyde kunder bidrar til at de trygges i sine handlinger og valg. Dette er prosesser som bidrar til å sosialisere lærlingene inn i yrket og praksisfellesskapet. Skule og Reichborn (2000) identifiserer høy eksponering for krav, altså i hvilken grad man er utsatt for krav fra kunder, kollegaer, ledere eller kjeden/konsernet som et forhold som stimulerer læring gjennom arbeidet.

I løpet av det året lærlingene hadde vært i bedriftene, mener både de selv og daglige ledere at de har utviklet seg hva gjelder modning og at de har blitt 
dyktigere i sitt arbeid gjennom å ha kommet bedre inn i yrkesrollen. De har fått bedre selvtillit i møte med kunder, og bedre kunnskap om produktene:

Sirklene har utvidet seg, selvtilliten har økt. Det har jeg forandret meg på. Derfor liker jeg å lese om produktene. Det gir meg trygghet. Men det er jo noe jeg må jobbe med selv. Det er ikke noe sjefen kan si. (Andreas, elektronikkforhandler B)

Jeg var jo dum som et brød i begynnelsen. Jeg har blitt mye mer sikker. Jeg kan alle produktene og nesten alle prisene i hodet. (Stine, skjønnhets- og velværeforretning)

I lærlingenes tolkning av yrkesrollen ligger også viktigheten av å være serviceorientert, smile, være høflig og se kundenes behov. Salgsarbeid har trekk av det Hochschild (1983) kaller "følelsesarbeid" (emotional labour). Begrepet favner å "manipulere" egne følelser i interaksjon med kunder, passasjerer, klienter eller brukere. Dette har ofte blitt sett på som noe pålagt og ønskelig fra arbeidsgivers side, og som de ansatte i slike yrker må håndtere. Derimot, som beskrevet av Brockmann (2013), kan dette også innebære positive aspekter, og hjelpe lærlingene inn i salgsyrket, som beskrevet av lærlingen i jernvarehandelen:

\begin{abstract}
Jeg har fått en mer positiv holdning, smiler mer, selv på de verste dagene med de verste kundene. Jeg synes det egentlig er positivt at jeg smiler, er sterk nok til å smile selv om det er kunder med skrikende unger, det har gjort at jeg nå er mindre redd for at kunder skal komme bort å snakke med meg, var jo i butikk tidligere en gang i uka og kom det kunder da så ble jeg veldig nervøs, visste ikke helt hva jeg skulle si der, men her klarer jeg det, føler jeg. (Silje, jernvarehandel)
\end{abstract}

På den andre siden kan også kundene fremstå som kilde til stress - "særlig når de kommer mange samtidig" (Tobias, sportsbutikk). Lærlingene forteller om at kunden også kan forårsake vanskeligheter og problemer. Da de ble spurt om de hadde opplevd noen vanskelige situasjoner hittil i sin læretid, oppga de fleste situasjoner som involverte kranglete kunder.

Samlet sett, var kundenes umiddelbare tilbakemelding på lærlingenes arbeid noe de selv opplevde som viktig og sentralt for læring - og som hoveddelen av arbeidet. De knyttet selv an til kundebehandling, service, høflighet, smile og evne til å "lese" kundens behov som de viktigste ferdighetene en skulle ha som en god salgsmedarbeider.

Tilbakemeldingsprosessene i salgsfaget fremstår som lite formalisert. Selv om lærlingene gjør kundene fornøyde, betyr ikke det nødvendigvis at de lærer det de skal. Neste avsnitt tar for seg en svært annen form for vurdering - anerkjennende vurdering gjennom gradvis overføring av ansvar for arbeidsoppgaver og arbeidsområder.

\title{
Anerkjennelse gjennom ansvar
}

Arbeid med gradvis mer tillit gjennom økt ansvar for oppgaver er en form for anerkjennende vurderingsform (Kvale, 2007; Skule \& Reichborn, 2000, 
Tanggaard, 2004). Lærlingene i salgsfaget fikk i ulik grad ansvar og mulighet til å prøve seg med arbeidsoppgaver utover kundebehandling. I flere av bedriftene fikk lærlingene ansvar for en egen avdeling for et produktsegment som for eksempel avdeling for lyd og bilde i elektronikkforretningen, frukt og grønt i dagligvareforretningen eller kjøkkenavdelingen $\mathrm{i}$ jernvarehandelen. Stor grad av tillit ble vist lærlingene. De arbeidet i stor grad selvstendig i møte med kunder og gjennomføring av salg. Dette ble av mange daglig ledere formulert som en eksplisitt strategi, at det var viktig at lærlingene fikk ansvar og utviste selvstendighet og initiativ. I dette ligger det en implisitt faglig vurdering og anerkjennelse (Reegård, 2015a; Wilbrandt, 2003).

Salgslærlingene ble kastet ut i arbeidsoppgavene fra dag én. På den ene siden kan man tenke seg at den konstante eksponeringen for kunder og perioder med stress, bidrar til et såkalt restriktivt læringsmiljø (Fuller \& Unwin, 2003), kjennetegnet av ugunstige læringsvilkår. På den andre siden, viser lærlingeintervjuene at ansvaret som kom med kundeinteraksjon og andre oppgaver, var viktig for læring og mestring. En viktig del av læringen er å få ansvar. Ansvar, som en følelse av personlig forpliktelse, kan være på flere nivåer. Det kan handle om ansvar for en kunde, en oppgave eller en avdeling i butikken. Gjennom ansvar kommer tilfredsstillelse og mestring ved å ivareta og fullføre ansvaret (Aarkrog, 2003; Hansen, 2003). Etter hvert som læretiden skrider fram, får og tar lærlingene stadig større ansvar.

Intervjuer: Hvordan har læretiden endret seg fra du startet her?

Lærling: Ja, det blir jo en stor forskjell. De føler jo at jeg kan ta mer ansvar nå. De stoler mer på deg, da. (Thomas, elektronikkforretning A)

Lærlingenes ansvarsområder varierte. Silje, lærlingen i jernvareforretningen og lærlingen i elektronikkforretning B hadde klart definert ansvar for hver sine avdelinger i butikken, henholdsvis kjøkken- og lyd og bilde-avdelingen. Førstnevnte lærling hadde i tillegg ansvar for å bestille inn varer til sin avdeling. Andre lærlinger fikk ansvar for å lage salgsutstillinger eller utarbeide kampanjer. I kiosk- og videobutikken ønsket daglig leder at lærlingen skulle lære alle oppgavene som falt under daglig leders ansvar. Dette gjald blant annet å bidra til å sette opp lister for hvem som skulle jobbe når. Ansvaret som ble gitt til lærlingene var i ulik grad del av en gjennomtenkt eller planmessig opplæringsstrategi fra daglig leders side. Mange var imidlertid opptatt av at lærlingen skulle være selvstendig, slik at "man ikke behøvde å løpe etter dem med en pekefinger" (Arne, daglig leder sportsbutikk). Utvalget bestod i hovedsak av lærlinger som er motiverte, interesserte og dyktige. Dette kan være lærlinger som selv oppsøker ansvar og tar initiativ, og som det er enkelt å gi ansvar til. Samtidig var lærlingene situert i et tillitsfullt læringsmiljø, der de opplevde at de kunne spørre om råd og hjelp, dersom de hadde behov for det. Overføringen av ansvar henger tett sammen med 
organiseringen av salgsarbeidet i butikkene. For det første bestod butikkene av relativt flat struktur, der lederen gjennomførte mange av de samme oppgavene som de øvrige ansatte. Videre arbeidet lederne tett på lærlingene i det daglige arbeidet. Dette innebar at det kunne være enklere for lederne å delegere ansvar til lærlingene, da de samtidig kunne være tett på for å støtte og kontrollere. For det andre, bestod praksisfellesskapene i hovedsak av andre unge (ofte deltidsansatte). I større grad gjaldt dette i dagligvarebutikken, sportsbutikken og skjønnhets- og velværeforretningen - enn i bilforhandleren og sportsbutikken. I de sistnevnte var de ansatte i hovedsak voksne som arbeidet fulltid. Dette betyr at lærlingen mange steder kunne være den eneste, eller en av få, som arbeidet fulltid, og fikk med dermed raskt mer ansvar.

Dette viser hvordan fullføring og mestring av gradvis økende ansvar bidrar til å fremme engasjement om egen opplæring og arbeid - noe står på spill - som igjen bidrar til utvikling av yrkesfaglig identitet og tilknytning til praksisfellesskapet. I et motsetningsforhold til den tillitsfulle, anerkjennende vurdering som beskrevet i det ovennevnte, står praksisen med registrering av summene lærlingene selger for på månedlig basis.

\section{Vurdering som kontroll}

Lærlingene fikk ingen forskjellsbehandling sammenlignet med de øvrig ansatte i noen retning. De fleste butikkene i utvalget praktiserte såkalt salgsregistrering. Det betyr at hver ansatt så vel som lærling, registrerte seg i kassa før varer ble slått inn, slik at denne salgssummen ble målt og presentert i et datasystem. Dette systemet var transparent i den forstand at andre ansatte og ledelsen kunne gå inn og se alles salgssum periodisert på dag, uke og måned. Enkelte lærlinger beskriver denne målingen som en motiverende faktor. Disse mente at det var på sin plass at ens salgssummer ble registrert og målt: "ja, det skulle bare mangle" (Jens, dagligvarebutikk). Elektronikkforhandleren delte ut premier (for eksempel en flaske vin eller et gavekort i butikken) til den beste selgeren hver måned, men ingen av butikkene koplet resultater på salgsregistreringen med lønn.

Det er gøy å gå inn og se hvor mye en har solgt for i måneden. Men jeg tar det mest som en konkurranse med meg selv. (Jon, elektronikkforhandler B)

De fleste lærlingene opplevde at dette var en helt grei praksis, noe som hørte med. For andre fungerte det derimot ikke like motiverende. Kanskje særlig for de lærlingene som ikke solgte for like store summer som andre ansatte, eksemplifisert gjennom sitatet fra Andreas i den ene elektronikkforhandleren:

Akkurat den konkurransen bryr jeg meg ikke så mye om. Du får tross alt timelønn og du skal jobbe hele tiden. Men det er viktig å ha fornøyde kunder. 
Andreas mener at man skal stå på uansett, ikke fordi man skal vinne en konkurranse. Han fortalte at selv om man ikke nødvendigvis fikk registrert så store salgssummer, kunne det være vel så viktig å sørge for at en kunde vil komme tilbake til butikken senere. Det symbolske arbeidet (Lamont \& Molnár, 2002) som Andreas utviser, gjør at han lettere kan stå i den situasjonen at hans salgstall kunne være lavere enn andre ansattes. Innholdet i denne formen for vurdering blir dermed frakoplet lærlingens subjektive fortolkning av det viktigste ved arbeidet og læringen.

Slik salgsregistering kan analyseres som en form for vurdering, der lærlingene kan sammenligne seg selv med andre. Denne vurderingsformen kan sammenlignes med karakterer fra skolebasert læring. Lærlingene får et uttrykk (salgssum) som vurdering og bedømming for den jobben de har gjort. Dette kan ses som en resultatorientert vurderingsform, og den kan virke disiplinerende. På den ene siden kan salgsregistreringen fortolkes som et uttrykk for ledernes behov for kontroll og oversikt over de ansatte og lærlingen. Tanggaard (2004) beskriver hvordan en slik vurderingsform oftere benyttes når det er lang avstand mellom vurderer og den som skal vurderes. Dette er derimot ikke tilfelle i salgsbedriftene, da lederne arbeider tett på lærlingene. Videre kan slik salgsregistrering tolkes som uttrykk for en mer omseggripende tendens knyttet til innføring av ulike typer "prestasjonsevaluerende verktøy", der de ansattes arbeid og produksjon skal reguleres og kontrolleres. Salgsregistrering kan relateres til yrkessosialisering på ulike måter. På den ene siden kan det virke motiverende, og lærlingene opplever seg som del av praksisfellesskapet på lik linje med de øvrig ansatte. På den andre siden kan lave salgssummer føre til at lærlingene orienterer seg mot andre aspekter av innholdet i opplæringen for å rettferdiggjøre handlinger, begrunnet med at det er ikke bare å selge mest mulig som gjelder. Service og kundebehandling handler om noe mer utover dette.

\section{Diskusjon}

Denne artikkelen har analysert tre svært ulike former for vurdering forankret i det daglige arbeidet i salgsfaget i Norge: kundens rolle i vurdering, samt formativ vurdering gjennom ansvar og tillit som lærlingene får på den ene siden gjennom gradvis overføring av ansvar, og salgsregistrering som vurderingsverktøy for kontroll og styring på den andre siden. Den internasjonale litteraturen om salgsarbeid betoner hvordan forholdet mellom ledelsens kontroll og kundenes krav utgjør hovedkilden til stress for de ansatte i detaljvarehandelen (Bélanger \& Edwards, 2013; Korczynski, 2009). Artikkelen argumenterer for relevansen av å forstå varehandelens logikk for å gripe de ulike vurderingspraksisenes betydning for lærlingene og deres sosialiseringsprosess inn i salgsfaget. Artikkelen har argumentert for at detaljvarehandelen er kjennetegnet av en distinkt vurderingslogikk sammenlignet med læretid innen andre sektorer av arbeidsmarkedet. 
Interaktivt servicearbeid som har kunden som omdreiningspunkt medfører at de tradisjonelle vurderingsaksene mellom vurderer (instruktør/faglig leder) og lærling må refortolkes. Lærlingene tillegger vurderingen fra kundene stor vekt, og anså fornøyde kunder som en innebygd del av arbeidets natur.

På den ene siden fører den svake institusjonaliseringen av salgsfaget til en "skolsk" dominans (Nore \& Lahn, 2014) i den skolebaserte yrkesrettede utdanningen - koplingen til arbeidslivet virker fjern i den daglige undervisningen. På den andre siden får den svake institusjonaliseringen av salgsfaget som lærefag uttrykk gjennom et produksjonsfokus, kanskje på bekostning av et pedagogisk fokus. Lederne på sin side har lav formalisert vurderingskompetanse og liten erfaring med å ha ansvar for lærlinger. Derimot har de lang erfaring med å lære opp nye (unge) ansatte i en sektor med høy turnover. Det at lærlingene selger mye, betyr ikke nødvendigvis at de også lærer mye. Med andre ord, vurderes hva de lærer eller hva de selger?

For det andre er den salgsspesifikke vurderingslogikken kjennetegnet av at lærlingene tidlig får mye ansvar. Dette kan tolkes som en anerkjennende vurderingsform. Lærlingene blir tatt på alvor, og får reelle arbeidsoppgaver med risiko og gevinst. Mestring og fullføring av ansvaret og tilliten de får bidrar til å integrere dem i arbeidsfellesskapet og derigjennom fremmer yrkessosialisering.

For det tredje, og i kontrast til den tillitsfulle gradvise overføringen av ansvar, innebærer salgsvurderingslogikken at lærlingene konstant vurderes basert på hvor store summer de har solgt for. På den ene siden opplever lærlingene at dette virker motiverende. På den andre siden kan lave salgssummer før til at lærlingene distanserer seg fra yrket de er på vei ut $\mathrm{i}$, da salgsregisteringen gir dem "dårlige karakterer" som kan virke demotiverende. Samtidig viste intervjuene at en lærling i stedet orienterte seg mot, og identifiserte seg med andre aspekter ved salgsyrket, da salgssummen ble lav.

Formativ vurdering og dets rolle i yrkessosialisering og faglig identitetsutvikling kan bidra til å skape følelse av tilhørighet til et fellesskap, yrkesstolthet, interesse og motivasjon. Dette kan fungere som integrerende betingelser i en utdanning ellers preget av høyt frafall. Hvorvidt de unge viser interesse for utdanningen og yrkesfeltet, og får bekreftet sine bestrebelser gjennom vurderingspraksiser, har implikasjoner for læringsmotivasjon - både i skole og bedrift (Reegård, 2015b).

Fokuset på vurderingslogikker framfor vurderingspraksiser handler om å gripe forhold innebygd i salgsarbeid med butikken som læringsarena og arbeidsplass - som har ulike vurderingspraksiser som uttrykk, framfor som sitt utgangspunkt. Denne artikkelen har vist relevansen av å forstå denne særegne logikken med et aktivt aktørperspektiv for å forstå de ulike yrkessosialiseringsprosessene som finner sted. Mer kunnskap er imidlertid savnet for å bedre fange betydningen av ulike vurderingsformer i kundeeksponerte sektorer, og hvordan vurdering som læring kan styrke den yrkessosialiserende prosessen. 
Når lærlingen møter arbeidslivets vurderingslogikk

\section{Slutnoter}

1 Prosjektperioden strakk seg fra 2011-2015, og var finansiert av Utdanningsdirektoratet. Studien ble gjennomført i samarbeid mellom NIFU, Universitetet i Bergen, Fafo og daværende Høgskolen i Oslo og Akershus.

${ }^{2}$ Se Olsen mfl. (2014) for mer om metode.

\section{Om forfatteren}

Kaja Reegård, PhD Sosiologi er forsker ved NIFU, Nordisk institutt for studier av innovasjon, forskning og utdanning. Hennes forskningsinteresser kretser rundt fagopplæringssystemet, frafall fra videregående opplæring og overganger fra utdanning til arbeid. 
Kaja Reegård

\section{Referanser}

Aarkrog, V. (2003). Læring i detaljhandel. I K. Nielsen \& S. Kvale (Red.), Praktikkens læringslandskab: At lære gennem arbejde (s. 43-54). København: Akademisk Forlag

Bélanger, J. \& Edwards, P. (2013). The nature of front-line service-work: Distinctive features and continuity in the employment relationship. Work, Employment and Society, 27(3), 433-450.

Berger, P.L. \& Luckmann, T. (1966). The social construction of reality: A treatise in the sociology of knowledge. London: Penguin Books.

Bore, L., Nyen, T., Reegård, K. \& Tønder, A.H. (2012). Internopplæring i varehandelen. Fafo-rapport 2012:23. Oslo: Fafo.

Brockmann, M. (2013). Learning cultures in retail: Apprenticeship, identity and emotional work in England and Germany. Journal of Education and Work, 26(4), 357-375.

Colley, H., James, D. Tedder, M. \& Diment, K. (2003). Learning as becoming in vocational education and training: Class, gender and the role of vocational habitus. Journal of Vocational Education and Training, 55(4), 471-496.

Dall' Alba, G. (2009). Learning professional ways of being: Ambiguities of becoming. Educational Philosophy and Theory, 41(1), 34-45.

Ecclestone, K. (2007). Commitment, compliance, and comfort zones: The effects of formative assessment on vocational education students' learning careers. Assessment in Education, 14(3), 315-333.

Engh, R., Dobson, S., Sandvik, L.V., Gamlem, S.M., Engvik, G., Hartberg, E. \& Tellefsen, (2012). Teoretisk bakgrunnsdokument for arbeid med implementering av vurdering for laering på ungdomstrinnet. Hentet 30. september 2020 fra https://www.udir.no/globalassets/upload/ungdomstrinnet/rammeverk/ungdomstrinnet_bakgrunnsdokument_vurdering_for_laring_vedlegg_5.pdf

Friche, N. (2010). Erhvervsskolers evalueringspraksis: Intentioner bag, anvendelse og virkning af evaluering i erhvervsuddannelserne. Ph.D-afhandling, Institut for Uddannelse, Læring og Filosofi. Aalborg: Aalborg Universitet.

Frønes, I. (1998). De likeverdige: Om sosialisering og de jevnaldrendes betydning. Oslo: Universitetsforlaget.

Fuller, A. \& Unwin, L. (2003). Learning as apprentices in the contemporary UK workplace: Creating and managing expansive and restrictive participation. Journal of Education and Work, 16(4), 407-426.

Gulikers, J.T.M., Bastiaens, T.J. \& Kirschner, P.A. (2008). Authenticity is in the eye of the beholder: Student and teacher perceptions of assessment authenticity. Journal of Vocational Education and Training, 60(4), 401-412. 
Hagen, A., Nadim, M. \& Nyen, T. (2010). Fagopplæring på nye felt: En kartlegging av virksomhetenes holdninger til nyere fag $i$ tjenesteytende virksomhet. Fafo-rapport 2010.12. Oslo: Fafo.

Hager, P. \& Hodkinson, P. (2009). Moving beyond the metaphor of learning. British Educational Research Journal, 35(4), 619-638.

Hansen, R. (2003). Læring gennem øget ansvar i en sportsbutik. I K. Nielsen \& S. Kvale (Red.), Praktikkens læringslandskab: At lære gennem arbejde (s. 55-68). København: Akademisk Forlag.

Hidi, S. \& Renninger, K.A. (2006). The four-phase model of interest development. Educational Psychologist, 41(2), 111-127.

Hochschild, A.R. (1983). The managed heart: Commercialisation of human feeling. Los Angeles, CA: University of California Press.

Høst, H., Seland, I. \& Skålholt, A. (2013). Yrkesfagelevers ulike tilpasninger til fagopplæring: En undersøkelse av elever $i$ tre yrkesfaglige utdanningsprogram $i$ videregående skole. NIFU-Rapport 16/2013. Oslo: NIFU.

Jordfald, B. \& Mühlbradt, M. (2015). Arbeidskraftbehov ved søndagsåpne butikker. Fafo-notat 2015:03. Oslo: Fafo.

Klotz, V.K., Billett, S. \& Winther, E. (2014). Promoting workforce excellence: Formation and relevance of vocational identity for vocational education and training. Empirical Research in Vocational Education and Training, 6(6), 1-20.

Korczynski, M. (2009). The mystery customer: Continuing absence in the sociology of service work. Sociology, 43(5), 952-967.

Kvale, S. (2007). Vurdering i skole - vurdering i bedrift. Presentasjon ved Landskonferansen 2007, Vurdering for/av læring, Utdanningsdirektoratet, Oslo, 1.-2. november 2007.

Lamont, M. \& Molnár, V. (2002). The study of boundaries in the social sciences. Annual Review of Sociology, 28, 167-195.

Lave, J. \& Wenger E. (1991). Situated learning. Cambridge: Cambridge University Press.

Meld. St. 20. (2012-2013). På rett vei: Kvalitet og mangfold i fellesskolen. Oslo: Kunnskapsdepartementet.

Nore, H. \& Lahn, L. (2014). Innhold og vurdering i bedriftsopplæringen. I H. Høst (Red.), Kvalitet i fag- og yrkesopplæringen: Fokus på opplæringen i bedrift (s. 85100). Rapport 3, Forskning på kvalitet i fag- og yrkesopplæringen. NIFU-rapport 12/2014. Oslo: NIFU.

Nyen, T., Skålholt, A. \& Tønder, A.H. (2015). Fagopplæring som vei inn i arbeidslivet. I H. Høst (Red.), Kvalitet i fag- og yrkesopplæringen (s. 173-229). Sluttrapport, Forskning på kvalitet i fag- og yrkesopplæringen. Oslo: NIFU.

Olsen, O.J. \& Reegård, K. (2013). Læringsmiljø og gjennomføring i lærer- og elevperspektiv i tre yrkesfaglige opplæringsløp. I H. Høst (Red.), Kvalitet i fag- og yrkesopplæringen: Fokus på skoleopplæringen (s. 17-72). Rapport 2, Forskning på kvalitet i fag- og yrkesopplæringen. NIFU-rapport 21/2013. Oslo: NIFU. 
Olsen, O.J., Reegård, K., Seland, I. \& Skålholt, A. (2014). På sporet av kvaliteter i lærlingenes læringsmiljø og overgang mellom skole og læretid. I H. Høst (Red.), Kvalitet i fag-og yrkesopplæringen: Fokus på opplæringen i bedrift (s. 17-83). Rapport 3, Forskning på kvalitet i fag- og yrkesopplæringen. NIFU-rapport 12/2014. Oslo: NIFU.

Olsen, O.J., Reegård, K., Seland, I. \& Skålholt, A. (2015). Læringsmiljø og gjennomføring. I H. Høst (Red.), Kvalitet i fag- og yrkesopplæringen (s. 83-144). Sluttrapport, Forskning på kvalitet i fag- og yrkesopplæringen. Oslo: NIFU.

Reegård, K. (2017). Contrasting prospects: the institutionalisation of VET for retail and office work in Norway. Journal of Vocational Education and Training, 69(4), 558-575.

Reegård, K. (2015a). Diversity of occupational orientations in Sales Vocational Education and Training. Journal of Education and Work, 29(6), 668-706.

Reegård, K. (2015b). Sales assistants in the making: Learning through responsibility. Vocations and Learning, 8(2), 117-133.

Skule, S. \& Reichborn, A. (2000). Lærende arbeid: En kartlegging av lærevilkår i norsk arbeidsliv. Fafo-rapport 333. Oslo: Fafo.

Tanggaard, L. (2004). Evaluering som regulering af læring. Tidsskrift for Arbeijdsliv, 6(4), 56-75.

Thornton, P.H, Ocasio, W. \& Lounsbury, M. (2012). The institutional logics perspective: A new approach to culture, structure and process. Oxford: Oxford University Press.

SSB. (2018). Næringenes økonomiske utvikling. Hentet 30. september 2020 fra https://www.ssb.no/naringer/

Utdanningsdirektoratet. (2020a). Søkere til videregående opplæring - utdanningsprogram. Søkertall videregående opplæring - analyse. Tabell skoleår 2015, søkere Vg1 skole Service og samferdsel. Hentet 30. september 2020 fra https://www.udir.no/tall-og-forskning/statistikk/statistikk-videregaendeskole/sokere-vgs/sokere-utdanningsprogram/

Utdanningsdirektoratet. (2020b). Yrkesfaglige utdanningsprogram fra høsten 2020. Hentet 30. september 2020 fra https://www.udir.no/laring-og-trivsel/lareplanverket/forsok-og-pagaende-arbeid/ny-tilbudsstruktur-og-nye-lareplaner-pa-yrkesfag/ny-tilbudsstruktur-i-fag--og-yrkesoplaringen/

Vibe, N., Frøseth, M.W., Hovdhaugen, E. \& Markussen, E. (2012). Strukturer og konjunkturer: Evaluering av Kunnskapsløftet. Sluttrapport fra prosjektet Tilbudsstruktur, gjennomføring og kompetanseoppnåelse i videregående opplæring. Rapport 26/2012. Oslo: NIFU.

Wilbrandt, J. (2003). Lærlinge i bevægelse: Mellem skole og virksomhed og fra lærling til svend. I K. Nielsen \& S. Kvale (Red.), Praktikkens læringslandskab: At lære gennem arbejde (s. 201-218). København: Akademisk Forlag. 